\title{
Earthquake Design Practice for Buildings
}


Downloaded by [] on [25/04/23]. Copyright @ ICE Publishing, all rights reserved. 


\section{Earthquake Design Practice for Buildings}

\section{Fourth edition}


Published by ICE Publishing, One Great George Street, Westminster, London SW1P 3AA.

Full details of ICE Publishing representatives and distributors can be found at: www.icebookshop.com/bookshop_contact.asp

\section{Other titles by ICE Publishing:}

Designers' Guide to Eurocode 8: Design of Bridges for Earthquake Resistance EN 1998-2

Michael Fardis, Basil Kolias and Alain Pecker. ISBN 978-0-7277-5735-7

Seismic Design of Foundations: Concepts and applications

Subhamoy Bhattacharya, Rolando P. Orense and Domenico Lombardi. ISBN 978-0-7277-6166-8

Forensic Engineering: Informing the Future with Lessons from the Past John Carpenter (ed). ISBN 978-0-7277-5822-4

www.icebookshop.com

A catalogue record for this book is available from the British Library

ISBN 978-0-7277-6455-3

(C) Institution of Civil Engineers 2021

ICE Publishing is a division of Thomas Telford Ltd, a wholly-owned subsidiary of the Institution of Civil Engineers (ICE).

All rights, including translation, reserved. Except as permitted by the Copyright, Designs and Patents Act 1988, no part of this publication may be reproduced, stored in a retrieval system or transmitted in any form or by any means, electronic, mechanical, photocopying or otherwise, without the prior written permission of the Publisher, ICE Publishing, One Great George Street, Westminster, London SW1P 3AA.

This book is published on the understanding that the author is solely responsible for the statements made and opinions expressed in it and that its publication does not necessarily imply that such statements and/or opinions are or reflect the views or opinions of the publishers. While every effort has been made to ensure that the statements made and the opinions expressed in this publication provide a safe and accurate guide, no liability or responsibility can be accepted in this respect by the author or publishers.

While every reasonable effort has been undertaken by the author and the publisher to acknowledge copyright on material reproduced, if there has been an oversight please contact the publisher and we will endeavour to correct this upon a reprint.

Cover photo: Sommati of Amatrice, Italy. The damage caused by the earthquake that hit central Italy in 2016.

Commissioning Editor: James Hobbs

Development Editor: Melanie Bell

Production Editor: Madhubanti Bhattacharyya

Marketing Specialist: April Nagy

Typeset by The Manila Typesetting Company

Index created by Laurence Errington

Printed and bound in Great Britain by TJ Books, Padstow, Cornwall 


\section{Contents}

Foreword

ix

About the authors

$\mathrm{xi}$

Acknowledgements

xiii

01

The nature of earthquake risk

1.1. Introduction - technical solutions are not sufficient

1.2. Earthquakes are different from other hazards

1.3. How the toll from earthquakes varies between societies

1.4. Preparing for earthquakes 4

1.5. When the earthquake strikes 5

1.6. Reconstruction and recovery 7

1.7. An appropriate response to the earthquake threat 8

1.8. Creating earthquake-resilient communities 10

References 11

$02 \ldots \ldots \ldots \ldots \ldots \ldots \ldots \ldots \ldots \ldots \ldots+$ Earthquake hazard $\quad 13$

2.1. World seismicity 13

2.2. Characterising earthquakes 14

2.3. Effects of earthquakes on people and the built environment

2.4. Measures of ground motion 19

2.5. Site effects 26

2.6. Seismic hazard assessment 28

2.7. Design earthquake motions 33

References $\quad 36$

$03 \ldots \ldots \ldots \ldots \ldots \ldots \ldots \ldots \ldots$ Seismic performance objectives and ductile design $\quad 39$

3.1. Seismic performance objectives $\quad 39$

3.2. Ductile building response 46

3.3. Capacity design 51

3.4. Performance-based seismic design 56

References 58

$04 \ldots \ldots \ldots \ldots \ldots \ldots \ldots \ldots \ldots \ldots \ldots$ Initial planning considerations and seismic codes 61

4.1. The lessons from earthquake damage 61

4.2. Planning considerations 62

4.3. Structural systems 84

4.4. Role of seismic codes in design $\quad 100$

References 108 


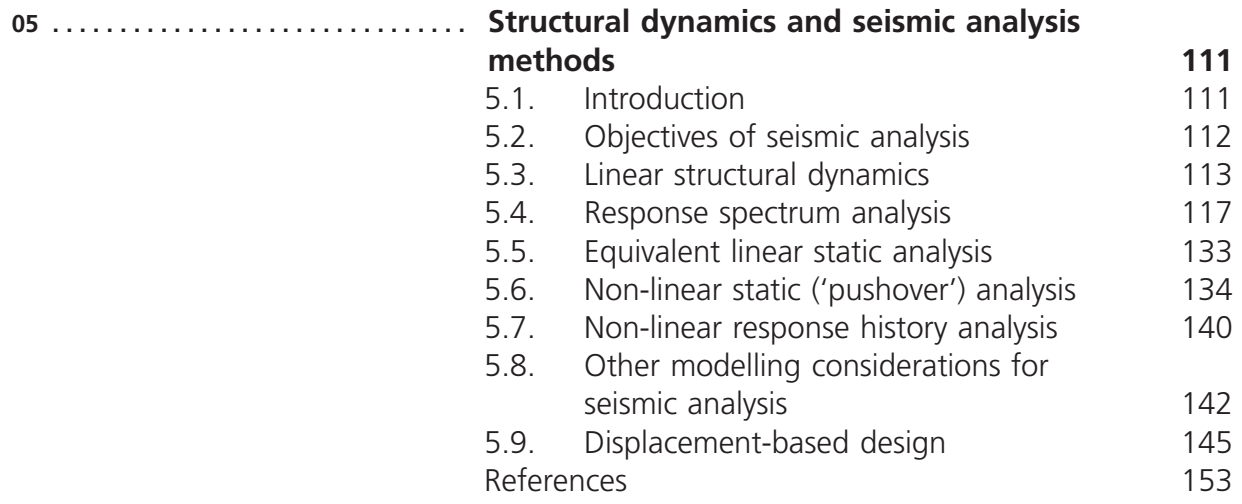

$06 \ldots \ldots \ldots \ldots \ldots \ldots \ldots \ldots \ldots \ldots$ Analysis of soils and soil-structure interaction 155

6.1. Soil properties for seismic design 155

6.2. Site response and wave passage effects 161

6.3. Soil-structure interaction 162

6.4. Liquefaction 165

6.5. Other site-specific hazards 174

References 175

$07 \ldots \ldots \ldots \ldots \ldots \ldots \ldots \ldots \ldots \ldots \ldots \ldots+$ Foundations and retaining structures $\quad 179$

7.1. Design objectives 179

7.2. Capacity design considerations for 180

7.3. Pad and strip foundations 182

7.4. Raft foundations 184

7.5. Pile foundations 185

7.6. Retaining structures 187

7.7. Design in the presence of liquefiable soils 189

References 190

$08 \ldots \ldots \ldots \ldots \ldots \ldots \ldots \ldots$ Reinforced concrete design 193

8.1. Introduction 193

8.2. Forms of reinforced concrete construction 193

8.3. Lessons from earthquake damage 194

8.4. Characteristics of reinforced concrete as a seismic resisting material 202

8.5. Behaviour of reinforced concrete components

8.6. Modelling and analysis of reinforced concrete buildings 215

8.7. Seismic design of reinforced concrete buildings 230

References 253 


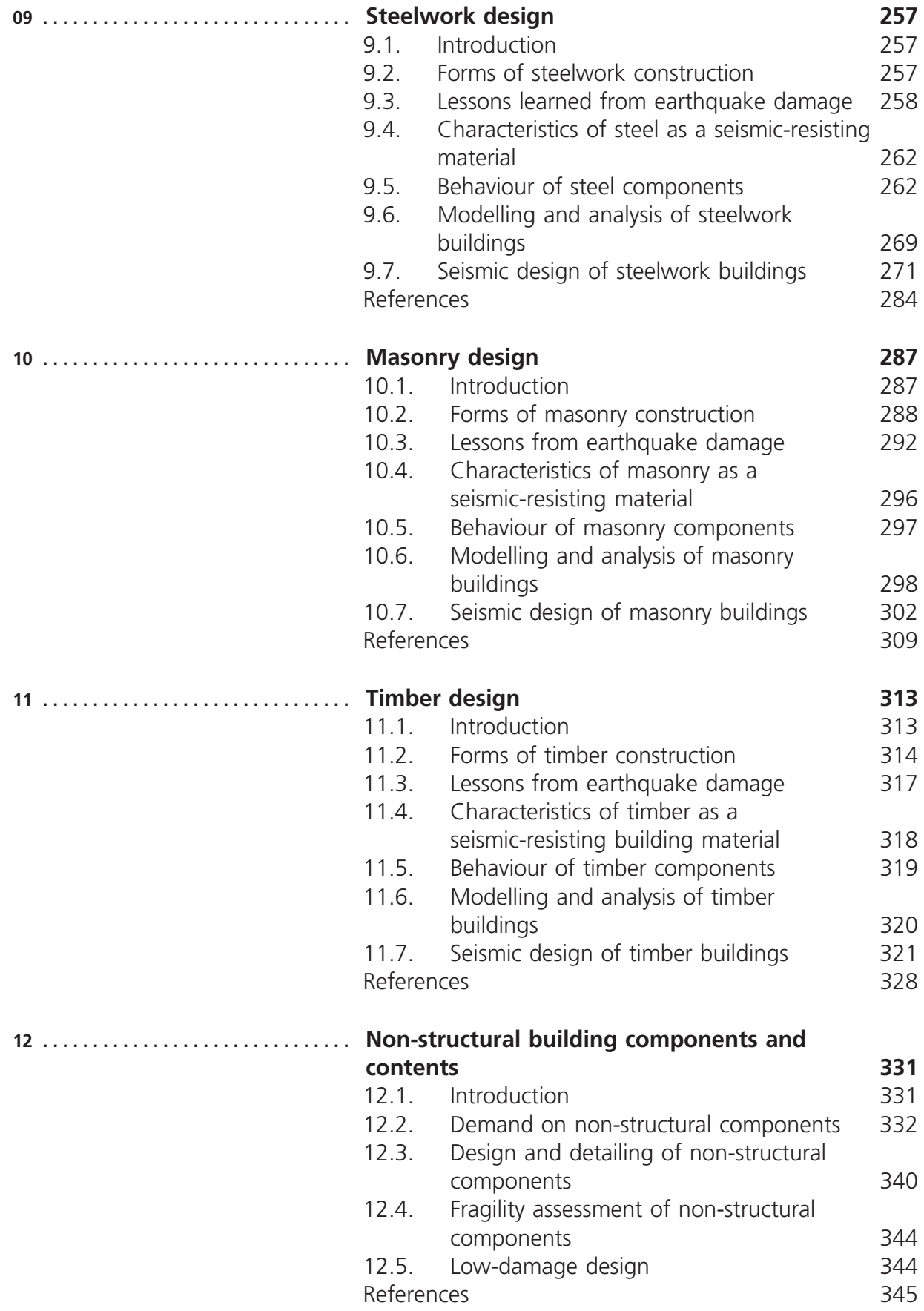


13.1. Introduction

13.2. Performance of buildings with seismic-protective technologies in earthquakes

13.3. Seismic isolation

13.4. Supplemental damping

13.5. Self-centring systems

13.6. Replaceable yielding devices

Assessment and strengthening of existing buildings

14.1. Risk management for existing buildings 14.2. Seismic assessment of existing buildings

Index 
Congratulations to Damian and Edmund for this very welcome contribution which I believe is an essential read for practitioners and students with interest in earthquake engineering. My own interest in the subject began in earnest some thirty years ago when, as an MSc student, I had the opportunity to join a reconnaissance team to examine the aftermath of the Loma Prieta earthquake in California. I was struck by the immensity of the damage inflicted on buildings and infrastructure, and the wider societal consequences. Since then, the subject has advanced beyond recognition and, as a result, there has been growing expectation that our built environment and communities would be seismically resilient, and that students and practitioners are educated and trained to address this. I have worked closely with the two authors for many years, through activities including teaching and training, code development and standardisation, and seismic design of real structures. Their vast collective experience in design, research, fieldwork, teaching and code committees make them ideally placed to offer unique insights into the fundamentals as well as advances and intricacies of the practical earthquake design of buildings.

This is the fourth edition of the book, and follows on from three widely read earlier editions published in 1998, 2006 and 2014. This edition includes significant additions that incorporate recent developments related to the seismic design, assessment, and rehabilitation of buildings. The main ingredients from the earlier versions are retained and updated, including aspects related to seismic risk and hazard, conceptual design approaches, static and dynamic analysis procedures, soil effects and design of foundations, and the design and strengthening of reinforced concrete, steel, masonry, and timber buildings. Apart from updates to the design procedures throughout the book, reflecting recent developments in codes of practice, there are notable additions to the chapters related to the design of masonry and timber buildings. The new aspects introduced in this edition, with respect to the background and application of performance-based earthquake engineering, are also particularly useful. Other highly valuable additions include those related to the use of modern seismic-protective technologies as well as the performance of non-structural components, both of which are vital for pursuing the growing drive towards providing resilient and low-damage seismic design. 
This book succeeds in achieving the difficult balance of being relatively straightforward to follow for an engineer with limited background in the subject, whilst being very informative and engaging for more experienced readers who want to update their knowledge and skills in seismic design. Although the main focus of the book is on the behaviour, design and assessment of buildings, it also raises awareness of the wider economic and societal considerations related to earthquake resilience. The book meets the needs of a wide international audience, as there is emphasis on explaining the underlying fundamental concepts without reliance on a specific code of practice. Nonetheless, the basis and procedures of a number of international design standards are presented, discussed and compared, including those from the European, North American, Indian and Chinese seismic codes. Overall, the knowledge, experience and insights shared in this edition make it a very valuable and highly recommended resource for those involved in the teaching of earthquake engineering and in the practical seismic design and assessment of buildings structures.

\author{
Ahmed Elghazouli FREng \\ Professor of Structural Engineering \\ Imperial College London
}




\section{About the authors}

Damian Grant is an Associate Director in Arup's Advanced Digital Engineering group, in London, UK, and leads the group's earthquake engineering team. He has a $\mathrm{PhD}$ in earthquake engineering from the ROSE School in Pavia, Italy. Since joining Arup in 2005, Damian has been responsible for the seismic design and assessment for a diverse range of projects, including buildings (from single-storey dwellings to super-tall skyscrapers), industrial facilities, offshore platforms, storage tanks, bridges and other special structures. He specialises in seismic risk assessment, performance-based earthquake engineering, and the application of seismic protective systems such as isolators and supplemental damping devices.

After 20 years with Arup and 5 years on site in the UK and West Africa, Edmund Booth has for 25 years run his own consultancy, specialising in seismic design, assessment and code development. He has been a visiting professor at Oxford University and is a fellow of the Royal Academy of Engineering. Edmund has prepared two books on earthquake engineering, including the second and third editions of this publication.

Damian and Edmund are involved in the development of the next editions of Eurocode 8, through the British national committee $(\mathrm{B} / 525 / 8)$ and the European Working Group 'Future Directions for Eurocode 8'. They both lecture on the Imperial College MSc course in earthquake engineering, and have made numerous contributions to journals, courses, conferences and books. 
Downloaded by [] on [25/04/23]. Copyright @ ICE Publishing, all rights reserved. 
The first author, Damian Grant, would like to thank the following people who provided inputs to various parts of this book: Manuela Villani supplied the data for Figure 2.9 and advised on its presentation; Chen Huang and Carmine Galasso compiled the information about Chinese codes in Table 4.1, and Jenny Pattison did the same for the Indian codes; Ulas Cilingir clarified some information on modulus reduction curves and non-linear models for liquefaction assessment in soils; Andrea Penna elucidated many aspects of the design of masonry structures; Vincenzo Reale thoroughly reviewed Chapter 11 on timber structures; Daniele Casagrande clarified non-linear backbone requirements for timber structures in the new draft Eurocode 8; and Didier Pettinga provided information on low-damage seismic design in New Zealand.

Previous editions of this book (of which much material remains in this fourth edition) benefited substantially from contributions by two very old friends of Edmund Booth, the second author - Jack Pappin and Richard Fenwick who provided comprehensive reviews of material now found in Chapters 6 and 7 (Jack) and Chapter 8 (Richard), and generously allowed some of the text in these chapters to be based on material originally prepared by them.

Thanks are due to the editorial staff at ICE Publishing, and in particular to James Hobbs.

Finally, Damian would like to thank Angela, who encouraged him to take on this project and supported him throughout particularly when lockdown struck towards the end of the writing process and quiet (child-free) thinking space was difficult to find! 